\title{
The Effects of Change in Fineness of Fly Ash on Air-Entraining Concrete
}

\author{
Hongzhu Quan*
}

School of Civil Engineering, Qingdao Agricultural University, Qingdao, Shandong, 266109, China

\begin{abstract}
Although the specific surface area of type-2 fly ash, specified to be not less than $250 \mathrm{~m}^{2} / \mathrm{kg}$ in Japanese Industrial Standard, type-2 fly ash manufactured and available range from $300 \mathrm{~m}^{2} / \mathrm{kg}$ to $450 \mathrm{~cm}^{2} / \mathrm{kg}$ in Japan. In order to make clear of the effects of change in fineness of fly ash on the properties of air-entraining concrete, 2 series of laboratory experiments were carried out using 6 kinds fly ash with the specific surface area in the range from $250 \mathrm{~m}^{2} / \mathrm{kg}$ to 440 $\mathrm{m}^{2} / \mathrm{kg}$. In the series 1 experiment, mix proportion was the same for 6 mixtures of fly ash, regardless of the change in fly ash properties. Water binder ratio, unit binder content, fly ash replacement ratio and unit water content were constant for all mixtures as well as the dosage of chemical admixture. In the series 2 experiment, 5 mixtures of concrete with the same materials, with the same unit binder content, with the same fly ash replacement ratio and with the same water binder ratio as those in the series 1 experiment were examined. However, unit water content and dosage of air-entraining agent were adjusted to obtain target slump and target air content. The test results indicated higher slump and lower air content and higher dosage of air-entraining agent for fly ash with higher specific surface area than those with lower specific surface area. Compressive strength was found to increase with the increases of specific surface area of fly ash, while drying shrinkage and carbonation were found to show different tendency with change in fineness of fly ash.
\end{abstract}

Keywords: Fly ash, type-2 fly ash, fineness, specific surface area, air-entraining concrete, compressive strength, drying shrinkage, carbonation.

\section{INTRODUCTION}

Although more than 5 million tons of fly ash is generated from coal burning power stations in a year in Japan, the use of fly ash in concrete is still limited, because of difficulty in quality control of air-entraining fly ash concrete [1-4]. Japanese Industrial Standard, JIS A 6201, 'Fly ash for Use in Concrete' [5], specifies 4 types of fly ash depending on fineness, ignition loss, flow value ratio and activity factor as shown in Table 1. Among 4 types of fly ash, type- 2 fly ash is commonly manufactured and available. JIS A 6201 specifies the lower limit of specific surface area of type- 2 fly ash as $250 \mathrm{~m}^{2} / \mathrm{kg}$, but does not specify the upper limit.

Consequently, the specific surface area of type- 2 fly ash available in Japan widely range from $300 \mathrm{~m}^{2} / \mathrm{kg}$ to 450 $\mathrm{m}^{2} / \mathrm{kg}$, which often cause excessive change in slump and air content and difficulty in quality control [6-8].

In order to make clear of the effects of change in fineness of fly ash on the properties of air-entraining concrete containing type- 2 fly ash, 2 series of laboratory experiments were carried out using 6 kinds fly ash with the specific surface area in the range from $250 \mathrm{~m}^{2} / \mathrm{kg}$ to $440 \mathrm{~cm}^{2} / \mathrm{kg}$.

Series 1 experiment was carried out to simulate the effects of change in fineness of type- 2 fly ash on the properties of concrete containing fly ash with $25 \%$ replacement ratio to Portland cement, assuming that the fineness of type- 2 fly ash widely changed without notice and concrete is mixed based on the same mix proportion.

*Address correspondence to this author at the School of Civil Engineering, Qingdao Agricultural University, Qingdao, Shandong, 266109, China; Tel: +86-532-88030416(office); +86-13792443322 (Mobile); Fax: +86-532-88030411; E-mail:quanhz719@yahoo.com.cn
Series 2 experiment was carried out to simulate the same change in fineness of fly ash and the effect on air-entraining concrete with the same mix proportion assuming that mix proportion such as water content, dosage of chemical admixture to get target slump and target air content.

In the series 1 experiment, 6 mixtures of concrete made of ordinary Portland cement, fly ash, crushed stone, river sand, water-reducing agent and air-entraining agent were tested for slump, air content, compressive strength, modulus of elasticity, drying shrinkage and carbonation. Mix proportion was the same for 6 mixtures of concrete, with the water binder ratio of 0.50 , unit binder content of $370 \mathrm{~kg} / \mathrm{m}^{3}$, fly ash replacement ratio of $25 \%$, unit water content of $185 \mathrm{~kg} / \mathrm{m}^{3}$. Dosage of water-reducing agent and air-entraining agent were constant for all mixtures. Consequently, slump and air content of 6 mixtures of concrete were changed with the change of the fineness of fly ash.

In the series 2 experiment, 5 mixtures of concrete with the same materials, the same unit binder content, the same fly ash replacement ratio and the same water binder ratio as those in the series 1 experiment were tested. However, unit water content and dosage of air- entraining agent were adjusted to obtain target slump and target air content.

\section{EXPERIMENTAL OVERVIEW}

\subsection{Materials Used}

\subsubsection{Fly Ash}

Fineness of fly ash used in the series 1experiment and series 2 experiment were adjusted in the range from 250 $\mathrm{m}^{2} / \mathrm{kg}$ to $440 \mathrm{~m}^{2} / \mathrm{kg}$ by blending type- 1 , type- 2 and type- 4 fly 
ash, which were produced at the same coal-burning power station at same time. Fig. (1) shows the scanning election micrograph of type-1, type- 2 and type- 4 fly ash. The properties of 3 types fly ash are shown in Table 2.

Blending ratio to adjust the fineness of fly ash for experiments and calculated value of specific surface area, density and ignition loss of blended fly ash are shown in Table 3.

\subsubsection{Cement}

Ordinary Portland cement with the density of $3.16 \mathrm{~g} / \mathrm{cm}^{3}$ and fineness of $331 \mathrm{~m}^{2} / \mathrm{kg}$ was used.

\subsubsection{Aggregates}

Coarse aggregate used was crushed stone made of Oume sand stone. The maximum size was $20 \mathrm{~mm}$, density in ovendried condition was $2.63 \mathrm{~g} / \mathrm{cm}^{3}$ and absorption was $1.01 \%$.

Fine aggregate used was river sand from Ohi-River. The maximum size was $5 \mathrm{~mm}$, density in oven-dried condition was $2.60 \mathrm{~g} / \mathrm{cm}^{3}$ and absorption was $1.08 \%$.

\subsubsection{Chemical admixture}

As chemical admixture, a water-reducing agent of lignosulphonic acid and an air-entraining agent of anionic type were used.

Table 1. Quality Standard of Fly Ash in Japan

\begin{tabular}{|c|c|c|c|c|c|c|c|}
\hline & & & \multicolumn{4}{|c|}{ JIS A 6201} & \multirow{2}{*}{$\begin{array}{l}\text { JASS } 5 \text { M-401 } \\
\text { Type-2 }\end{array}$} \\
\hline & & & Type-1 & Type-2 & Type-3 & Type-4 & \\
\hline \multicolumn{3}{|c|}{$\mathrm{SiO}_{2}(\%)$} & \multicolumn{4}{|l|}{$45.0 \leq$} & $45.0 \leq$ \\
\hline \multicolumn{3}{|c|}{ Hygroscopic moisture (\%) } & \multicolumn{4}{|l|}{$\leq 1.0$} & $\leq 1.0$ \\
\hline \multicolumn{3}{|c|}{$\operatorname{Ig}$ loss $\quad(\%)$} & $\leq 3.0$ & $\leq 5.0$ & $\leq 8.0$ & $\leq 5.0$ & $\leq 4.0$ \\
\hline \multicolumn{3}{|c|}{ Density $\quad\left(\mathrm{g} / \mathrm{cm}^{3}\right)$} & \multicolumn{4}{|l|}{$1.95 \leq$} & $1.95 \leq$ \\
\hline \multirow{2}{*}{ Fineness } & \multicolumn{2}{|c|}{ Residue of $45 \mu \mathrm{m}$ sieve $(\%)$} & $\leq 10$ & $\leq 40$ & $\leq 40$ & $\leq 70$ & $\leq 10$ \\
\hline & \multicolumn{2}{|c|}{ Specific surface area $\left(\mathrm{m}^{2} / \mathrm{kg}\right)$} & $500 \leq$ & $250 \leq$ & $250 \leq$ & $150 \leq$ & $300 \leq$ \\
\hline \multicolumn{3}{|c|}{ Percent flow of mortar $(\%)$} & $105 \leq$ & $95 \leq$ & $85 \leq$ & $75 \leq$ & $100 \leq$ \\
\hline \multirow{2}{*}{\multicolumn{2}{|c|}{ Strength activity of Mortar (\%) }} & 28days & $90 \leq$ & $80 \leq$ & $80 \leq$ & $60 \leq$ & $90 \leq$ \\
\hline & & 91days & $100 \leq$ & $90 \leq$ & $90 \leq$ & $70 \leq$ & $100 \leq$ \\
\hline
\end{tabular}

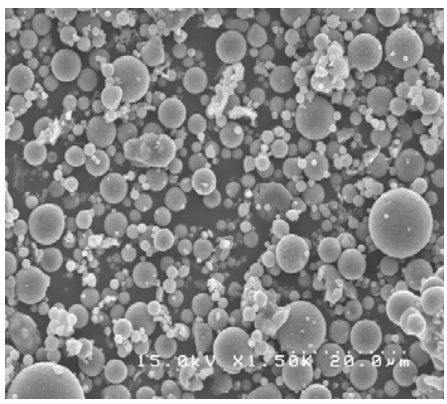

a) type-1 fly ash

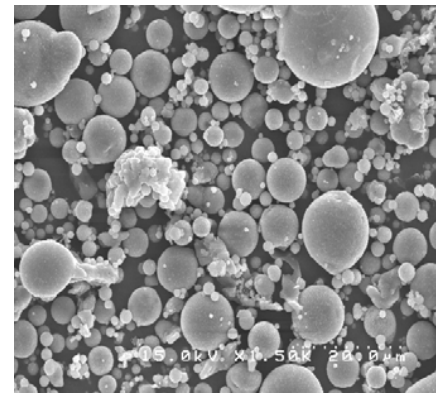

b) type-2 fly ash

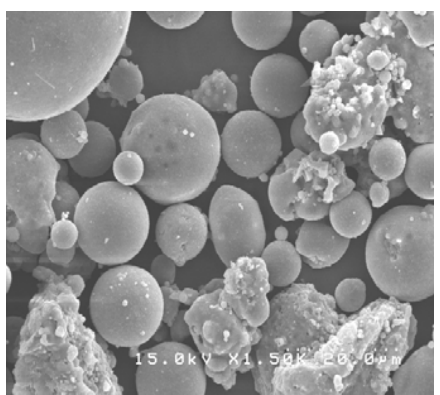

c) type-4 fly ash

Fig. (1). Scanning electron micrograph of fly ash used. 
Table 2. Type and Quality of Fly Ash Used

\begin{tabular}{|c|c|c|c|c|c|c|c|c|}
\hline & \multirow{2}{*}{$\mathrm{SiO}_{2}(\%)$} & \multirow{2}{*}{$\begin{array}{l}\text { Density } \\
\left(\mathrm{g} / \mathrm{cm}^{3}\right)\end{array}$} & \multirow{2}{*}{$\begin{array}{l}\text { Specific Surface } \\
\text { Area }\left(\mathbf{m}^{2} / \mathbf{k g}\right)\end{array}$} & \multirow{2}{*}{ Ig Loss (\%) } & \multirow{2}{*}{$\begin{array}{c}\text { Adsorption of } \\
\operatorname{MB}(\%)\end{array}$} & \multirow{2}{*}{$\begin{array}{l}\text { Percent Flow of } \\
\text { Mortar (\%) }\end{array}$} & \multicolumn{2}{|c|}{ Strength Activity of Mortar (\%) } \\
\hline & & & & & & & 28 Days & 91 Days \\
\hline Type-1 & 60 & 2.39 & 507 & 0.9 & 0.31 & 114 & 93 & 111 \\
\hline Type-2 & 60 & 2.29 & 376 & 0.9 & 0.39 & 107 & 84 & 103 \\
\hline Type-3 & 57 & 2.15 & 197 & 1.7 & 0.43 & 104 & 74 & 86 \\
\hline
\end{tabular}

Table 3. Blending Ratio and Calculated Qualities of Blended Fly Ash

\begin{tabular}{|c|c|c|c|c|c|c|c|c|}
\hline & - & F1 & F2 & F3 & F4 & F5 & F6 & - \\
\hline Type-1 & - & - & - & - & - & $30 \%$ & $50 \%$ & $100 \%$ \\
\hline Type-2 & - & $30 \%$ & $50 \%$ & $70 \%$ & $100 \%$ & $70 \%$ & $50 \%$ & - \\
\hline Type-3 & $100 \%$ & $70 \%$ & $50 \%$ & $30 \%$ & - & - & - & - \\
\hline Specific surface area $\left(\mathrm{m}^{2} / \mathrm{kg}\right)$ & 197 & 251 & 287 & 332 & 376 & 409 & 442 & 507 \\
\hline Density $\left(\mathrm{g} / \mathrm{cm}^{3}\right)$ & 2.15 & 2.19 & 2.22 & 2.25 & 2.29 & 2.32 & 2.34 & 2.39 \\
\hline Ig loss $(\%)$ & 1.7 & 1.5 & 1.3 & 1.1 & 0.9 & 0.9 & 0.9 & 0.9 \\
\hline
\end{tabular}

\subsection{Mix Proportion}

\subsubsection{Series 1 Experiment: The Experiment of Concrete Mix Proportion Fixed}

Table 4 shows the basic mixture proportion containing type-2 fly ash. The target slump was $180 \mathrm{~mm}$, the target air content was $4.5 \%$, water binder ratio was 0.50 and fly ash replacement ratio to cement was $25 \%$. Although, the mix proportion shown in Table $\mathbf{4}$ were designed to get the target slump and the target air content when F4 fly ash with the specific surface area of $376 \mathrm{~m}^{2} / \mathrm{kg}$ was used. However, when another fly ash, such as F1, F2, F3, F5 and F6, were used, slump, air content and unit weight will change due to the change in fly ash properties such as fineness, density and ignition loss, though water binder ratio is constant.

\subsubsection{Series 2 Experiment: The Effects of Change in Fine- ness of Fly Ash on Air-Entraining Concrete in the Case of Mix Proportion Adjusted}

Table 5 shows 5 mixtures of concrete containing F1, F2, F3, F4 and F5 fly ash shown in Table 3. Target slump of 180 $\mathrm{mm}$, target air content of $4.5 \%$, fly ash replacement ratio of $25 \%$ and water binder ratio of 0.50 were the same as those in the series 1 experiment. Mix proportion of concrete containing F4 fly ash is the same as shown in Table 4. Mix proportion of those containing F1, F2, F3 and F5 fly ash was adjusted with unit water content, unit sand content and the dosage of air-entraining agent in order to gain target slump, target air content and constant bulk volume. Unit binder content was changed consequently.

\subsection{Test Procedures}

\subsubsection{Series 1 Experiment: The Experiment of Concrete Mix Proportion Fixed}

6 mixtures of concrete containing type- 2 fly ash, F1 to F6 respectively, were mixed with a 50 liters pan type mixer in constant temperature room at $20^{\circ} \mathrm{C}$.

Fresh concretes were tested for slump, air content, unit weight and temperature of concrete, and cylindrical specimens $100 \mathrm{~mm}$ in diameter and $200 \mathrm{~mm}$ in height for compressive strength were molded. Cylindrical specimens were cured in water at $20^{\circ} \mathrm{C}$ and were tested for compressive strength at the age of 7 days, 28 days, and 91 days.

\subsubsection{Series 2 Experiment: The Experiment of Concrete} Mix Proportion Adjusted with Slump and Air Content Fixed

5 mixtures of concrete containing type-2 fly ash, F1 to F5 respectively, were mixed with the same method as in the series 1 experiment.

Table 4. Designed Mixture Proportion of Original (F4) Concrete

\begin{tabular}{|c|c|c|c|c|c|c|c|c|c|c|}
\hline & \multirow{2}{*}{$\begin{array}{l}\text { Target Slump } \\
\qquad(\mathrm{cm})\end{array}$} & \multirow{2}{*}{$\begin{array}{c}\text { Target Air } \\
\text { Content (\%) }\end{array}$} & \multirow{2}{*}{$\mathrm{W} / \mathrm{B}(\%)$} & \multirow{2}{*}{$\mathrm{W} / \mathrm{C}(\%)$} & \multirow{2}{*}{ s/a $(\%)$} & \multicolumn{5}{|c|}{ Weight $\left(\mathrm{kg} / \mathrm{m}^{3}\right)$} \\
\hline & & & & & & Water & Cement & Fly Ash & Sand & Crush Stone \\
\hline $\mathrm{F} 4$ & 18 & 4.5 & 50 & 67 & 42.9 & 185 & 278 & 93 & 724 & 975 \\
\hline
\end{tabular}


Table 5. Designed Mixture Proportion of Series 2 Experiment

\begin{tabular}{|c|c|c|c|c|c|c|c|c|c|c|c|}
\hline & W/B (\%) & $\mathrm{W} / \mathrm{C}(\%)$ & s/a (\%) & \multicolumn{5}{|c|}{ Weight $\left(\mathrm{kg} / \mathrm{m}^{3}\right)$} & $\begin{array}{c}\text { Air-Entraining } \\
\text { Agent }(B \times \%)\end{array}$ & \multicolumn{2}{|c|}{ Flesh Concrete } \\
\hline $\mathrm{F} 2$ & 51.1 & 68.1 & 43.2 & 186 & 273 & 91 & 734 & 975 & 0.062 & 180 & 4.2 \\
\hline $\mathrm{F} 3$ & 50.5 & 67.4 & 43.3 & 184 & 273 & 91 & 736 & 975 & 0.066 & 183 & 4.7 \\
\hline F5 & 49.5 & 65.9 & 43.4 & 180 & 273 & 91 & 740 & 975 & 0.076 & 183 & 4.9 \\
\hline
\end{tabular}

Fresh concrete were tested for slump, air content, unit weight and temperature of concrete, and then specimens for compressive strength, modulus of elasticity, drying shrinkage and carbonation tests were molded. Cylindrical specimens $100 \mathrm{~mm}$ in diameter and $200 \mathrm{~mm}$ in height were cured in water at $5^{\circ} \mathrm{C}, 10^{\circ} \mathrm{C}, 15^{\circ} \mathrm{C}$, and $20^{\circ} \mathrm{C}$ and cured in air at $20^{\circ} \mathrm{C}$ in sealed condition. Compressive test specimens cured in water at $5^{\circ} \mathrm{C}, 10^{\circ} \mathrm{C}$ and $15^{\circ} \mathrm{C}$ were tested at 28 days, those cured in water at $20^{\circ} \mathrm{C}$ were tested at 7 days, 28 days and 91 days and sealed specimens cured at $20^{\circ} \mathrm{C}$ were tested at 91 days. Modulus of elasticity was measured at the time of compressive strength tests.

$100 \mathrm{~mm}$ by $100 \mathrm{~mm}$ by $400 \mathrm{~mm}$ prism specimens for drying shrinkage test were cured in water until the age of 7 days and were kept at $20^{\circ} \mathrm{C}$ and $60 \%$, R.H. and were tested for length change for 91 days. And $100 \mathrm{~mm}$ by $100 \mathrm{~mm}$ by $400 \mathrm{~mm}$ prism specimens for carbonation, cured in water at $20^{\circ} \mathrm{C}$ for 28 days and air dried for 28 days, were stored in accelerating carbonation chamber at $20^{\circ} \mathrm{C}, 60 \%$ R.H. and $5 \%$ $\mathrm{CO}_{2}$ concentration.

\section{TEST RESULTS AND DISCUSSIONS}

\subsection{Changes in Fineness of Fly Ash}

As shown in Fig. (1) and Table 2, the specific surface area was $507 \mathrm{~m}^{2} / \mathrm{kg}$ for type- 1 fly sah, $376 \mathrm{~m}^{2} / \mathrm{kg}$ for type- 2 fly ash and $197 \mathrm{~m}^{2} / \mathrm{kg}$ for type-4 fly ash respectively. Although, the difference in quality of 3 types fly ash is little, the small difference in density and mortar tests can be resulted from change in fineness of fly ash [9].

As shown in Table 3, the specific surface area of 376 $\mathrm{m}^{2} / \mathrm{kg}$ of F4 fly ash was almost the same average value 380 $\mathrm{m}^{2} / \mathrm{kg}$ of type-2 fly ash used in Japan [1]. The calculated density of blended fly ashes increased and ignition loss of those decreased with the increase of specific surface area.

\subsection{Series 1 Experiment: The Experiment of Concrete Mix Proportion Fixed}

Fig. (2) shows the relationship between specific surface area of fly ash and slump of concrete. Fig. (3) shows the relationship between specific surface area and unit water content correlated by air content and unit weight. Correlation was made to adjust volume change due to change in entrained air and change of bulk of fly ash caused by the difference of density with specific surface area. Slump of concrete was found to be increased with the increase of specific surface area of fly ash, while unit water content increase with increase of specific surface area too.

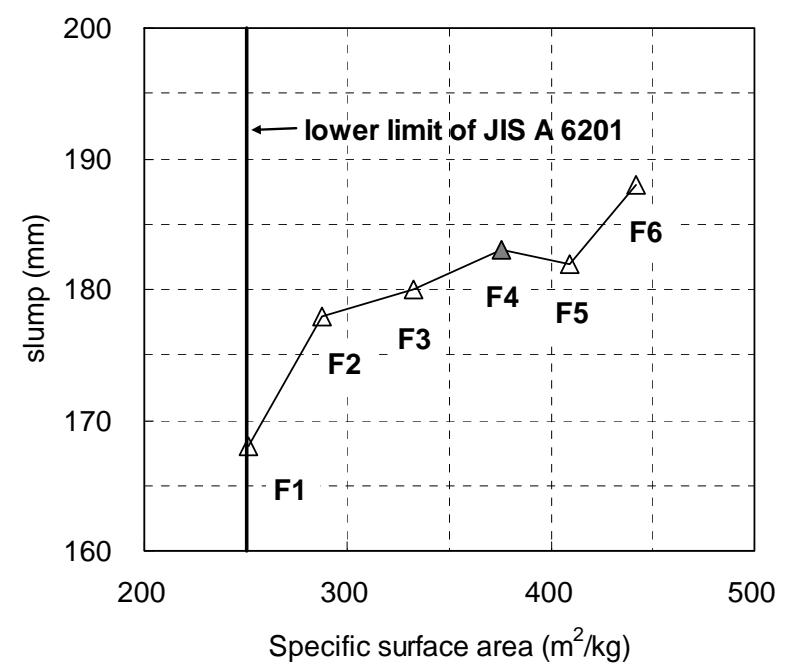

Fig. (2). Relations between fineness and slump.

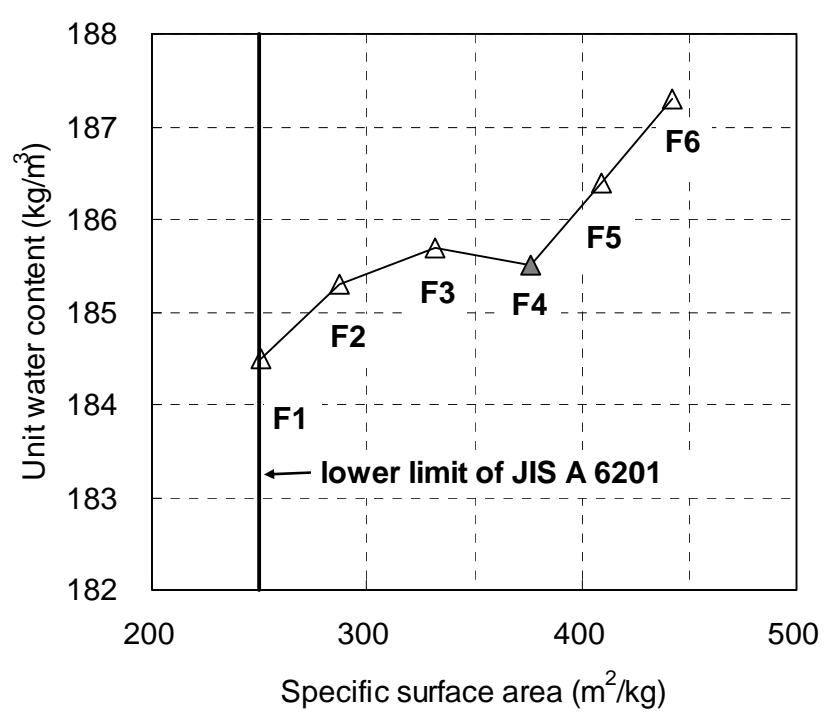

Fig. (3). Relations between fineness and unit water content.

Fig. (4) shows the relationship between specific surface area and air content of concrete. Entrained air showed a ten- 
dency to despite the decrease in ignition loss of fly ash. Air entraining capacity of air-entraining agent could be adversely affected with the increase of specific surface area. And reduction in slump with the increase in specific surface area could be affected with the reduction in air content as well [10].

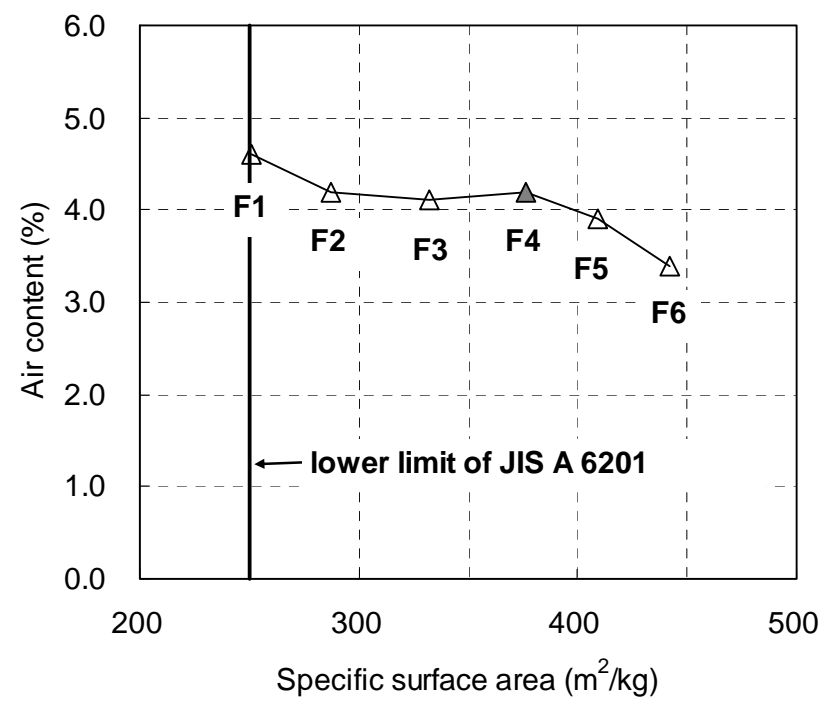

Fig. (4). Relations between fineness and air content.

Fig. (5) shows the relationship between specific surface area of fly ash and compressive strength at age of 7 days, 28 days and 91 days. Compressive strength was found to increase with the increase of specific surface area. Though, strength gain from 28 days to 91 days was found to be smaller for larger specific surface area.

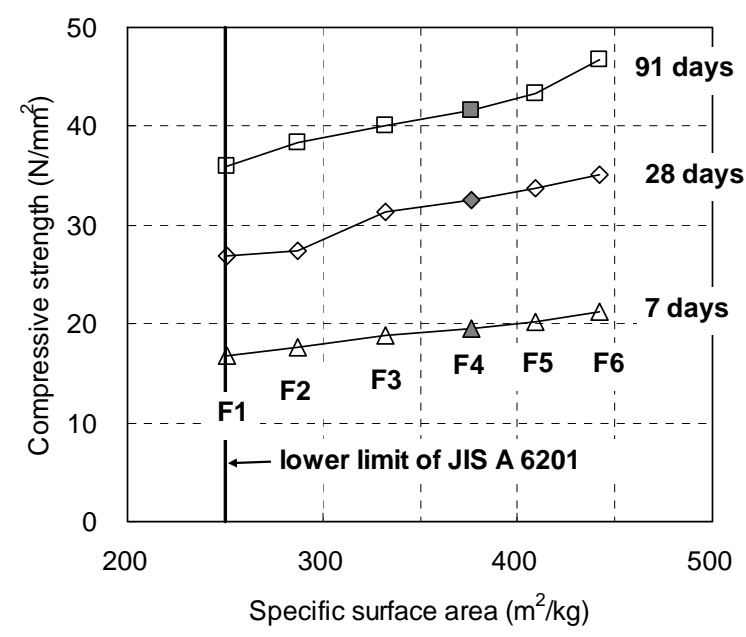

Fig. (5). Relations between fineness and compressive strength.

Change in specific surface area of fly ash of $\pm 125 \mathrm{~m}^{2} / \mathrm{kg}$ from $376 \mathrm{~m}^{2} / \mathrm{kg}$ was found to cause $\pm 15 \mathrm{~mm}$ slump change from $180 \mathrm{~mm}, \pm 0.8 \%$ air content change from $4.5 \%$ and $\pm 5.7 \mathrm{~N} / \mathrm{mm}^{2}$ compressive strength change from $32 \mathrm{~N} / \mathrm{mm}^{2}$ at 28 days.
3.3. Series 2 Experiment: The Experiment of Concrete Mix Proportion Adjusted with Slump and Air Content Fixed

Target slump and target air content were obtained by adjusting unit water content and dosage of air entraining agent. Fig. (6) shows the relationship between specific surface area and unit water content. Unit water content was to gain slump of $180 \mathrm{~mm}$ decrease linearly with the increase of fineness of fly ash. Consequently, water binder ratio decreased with the increase of specific surface area of fly ash.

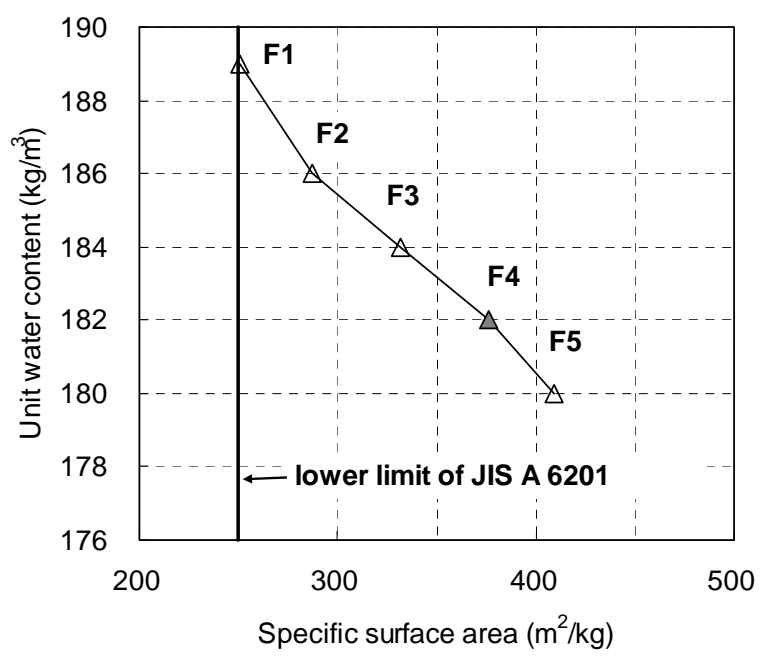

Fig. (6). Relations between fineness and unit water content.

Fig. (7) shows the relationship between specific surface area and dosage of air-entraining agent per $1 \%$ air entrainment. Dosage of air-entraining agent showed a tendency to increase with the increase of fineness of fly ash, because airentraining agent was adsorbed by the unburned activated carbon in fly ash, which reduces the air-entraining capability of concrete [11].

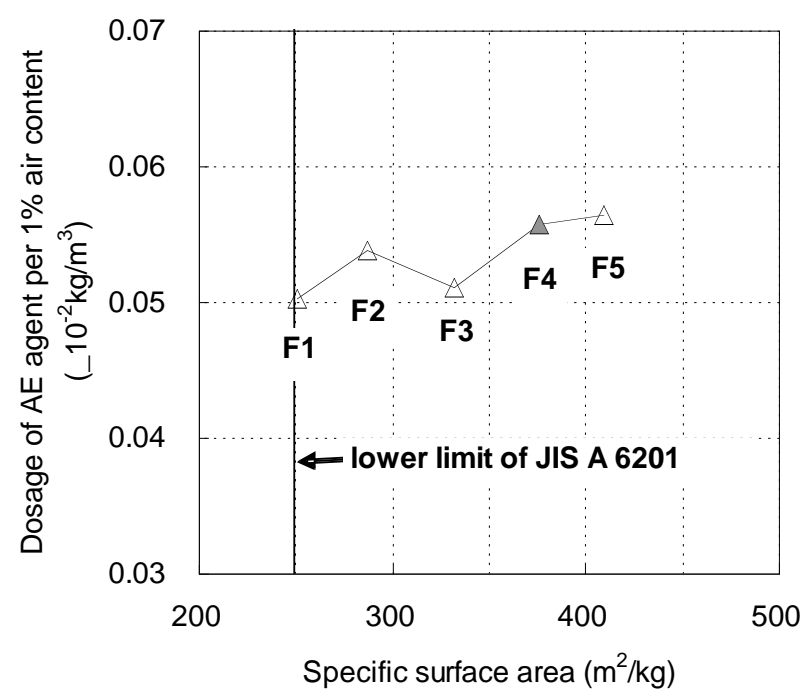

Fig. (7). Relations between fineness and dosage of AE agent par $1 \%$ air content. 


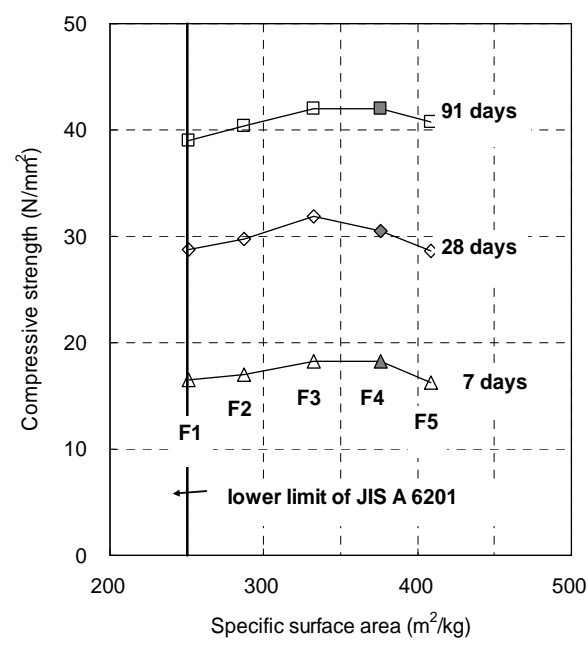

(a) Cured in water at 20

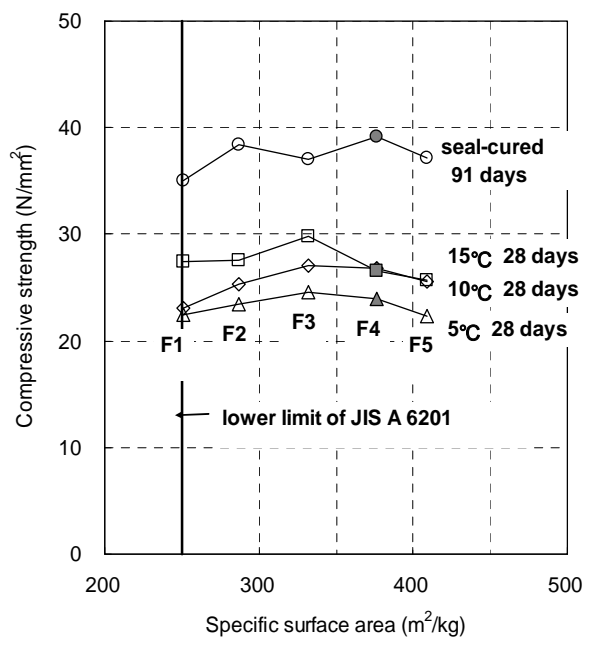

(b) Cured in other condition

Fig. (8). Relations between fineness and compressive strength.

Fig. (8) shows the relationship among specific surface area, compressive strength, test age and curing condition. Test results of compressive strength showed different tendency from Fig. (6) in the series 1 experiment. Compressive strength showed maximum value at the intermediate specific surface area independent of test age and curing condition. Compressive strength did not increase with the linear increase of specific surface area and with the consequent decrease of water binder ratio, which suggests that the hydration of fly ash is affected with the fineness of fly ash. And reduction in compressive due to low temperature curing was found to be greater for higher specific surface area [12].

Fig. (9) shows the relationship among maturity factor, fineness of fly ash and compressive strength. Although, compressive strength was increase linearly with maturity, strength gain of F4 concrete is greater than other fly ash with finer of coarser fly ash than F4 fly ash.

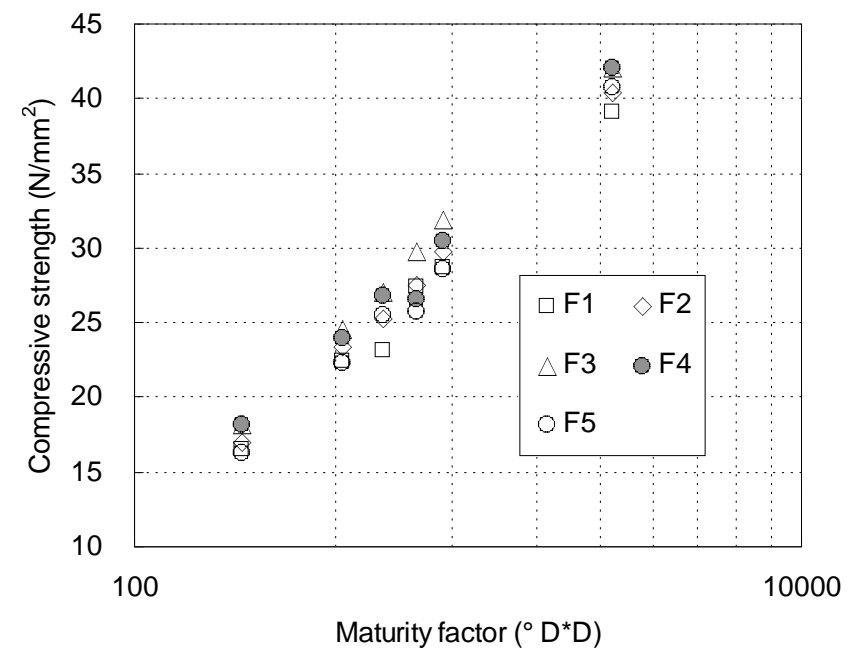

Fig. (9). Relations between maturity factor and compressive strength.

Fig. (10) shows the relationship among specific surface area, test age and modulus of elasticity of concrete. Modulus of elasticity at 7 days and 28 days showed the same tendency as compressive strength, but 91 days showed different tendency to decrease with the increase of specific surface area.

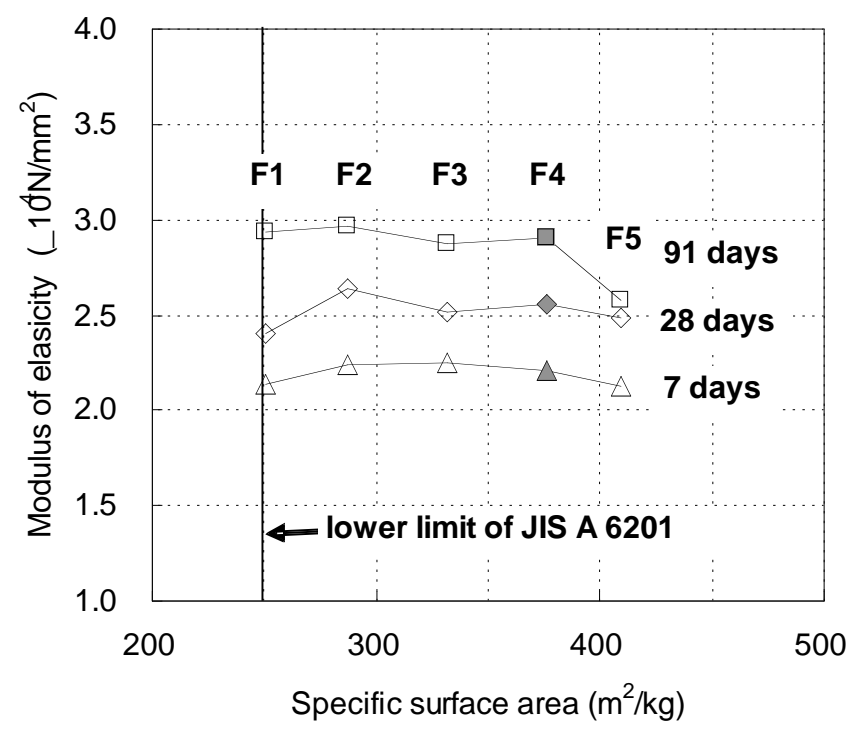

Fig. (10). Relations between maturity factor and modulus of elasticity.

Fig. (11) shows the relationship between specific surface area of fly ash and drying shrinkage. Drying shrinkage did not decrease with the decrease of specific surface area, but showed the minimum value at $376 \mathrm{~m}^{2} / \mathrm{kg}$ of $\mathrm{F} 4$ and increased at $409 \mathrm{~m}^{2} / \mathrm{kg}$ of F5. Therefore, the decrease of drying shrinkage was not only due to water reducing effect with the fineness of fly ash increased, but also might be due to the change of cement paste microstructure with fly ash [13].

Fig. (12) shows the relationship between specific surface area of fly ash and carbonation depth at accelerated carbonation test. Carbonation showed practically no change with the change of fineness of fly ash, despite the change in water binder ratio and in compressive strength [14]. 


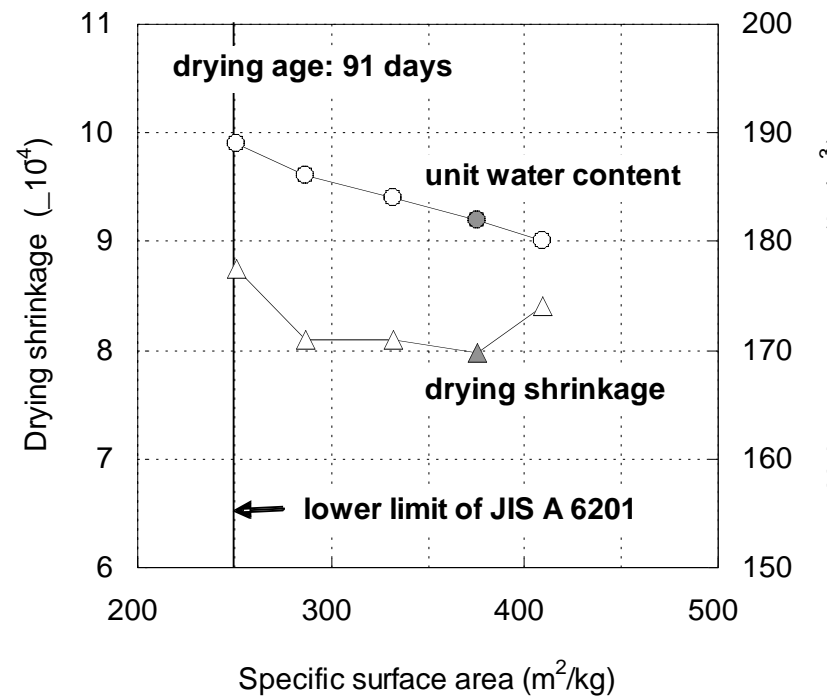

Fig. (11). Relations between maturity factor and drying shrinkage, unit water content.

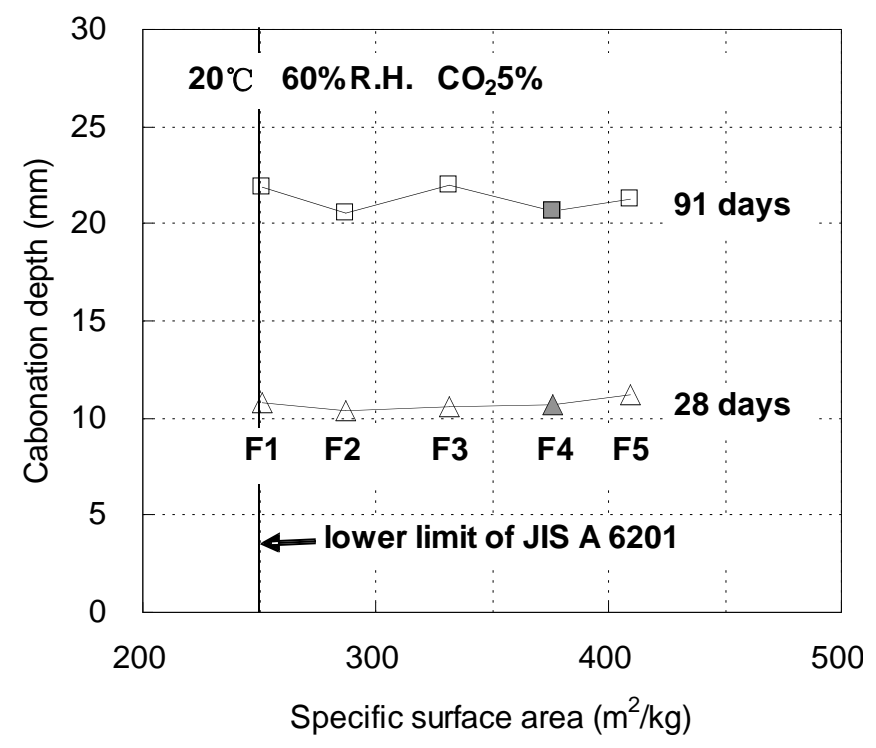

Fig. (12). Relations between maturity factor and carbonation depth.

\section{CONCLUSION}

The following conclusions were drawn from the experimental work presented in this paper on the effects of change in fineness of fly ash on the properties of air-entraining concrete containing fly ash with $25 \%$ replacement to Portland cement.

1) With the increase of the specific surface area of fly ash, the density of fly ash increased and the ignition loss decreased.

2) Supposing that the fineness of fly ash changed without notice to the ready-mixed concrete factory and no adjustment is made on mix proportion such as the weighing value of concrete materials such as water, cement, fly ash, sand, gravel or crushed stone and chemical admixture, properties of ready-mixed concrete mixture would be changed; the compressive strength being decreased with the same water binder ratio, decreased slump, increased air content when the fineness of fly ash decreased and the compressive strength being increased with increased slump, decreased air content when the fineness of fly ash increased.

3) Supposing that the fineness of fly ash changed without notice to the ready-mixed concrete factory and adjustment of weighing value of water and air-entraining agent is made in order to keep the target slump and air content, the compressive strength would decrease with the increased water content, increased water binder ratio and increased drying shrinkage when the fineness of fly ash decreased, and the compressive strength would increase with the decreased water content and decreased water binder ratio when the fineness of fly ash increased.

4) As a result, the change in fineness of fly ash great influenced the air-entraining capacity, water content, compressive strength and drying shrinkage of fly ash concrete.

\section{ACKNOWLEDGEMENT}

This research is supported by High-level Talents Start Fund of Qingdao Agricultural University (No. 630730).

\section{REFERENCES}

[1] Y. Ishikawa, S. Takada and H. Kasami, "Research on the quality distribution of JIS type-2 fly ash", AIJ J. Technol. Des., vol.25, pp. 1-6, Dec. 2006. (in Japanese)

[2] H. Quan and H. Kasami, "Durability of fly ash concrete affected with particle sizes of fly ash and replacement ratio to Portland cement ", In: Proc. of $10^{\text {th }}$ International Conference of Building Materials and Components, 2005, pp. 68-75.

[3] H. Quan and H. Kasami, "Experimental study on effects of the type and replacement ratio of fly ash on strength and durability of concrete", J. Struct. Constr. Eng., AIJ, no. 602, pp. 1-7, Apr. 2006. (in Japanese)

[4] K. Funamoto, "Study on compressive strength development of concrete with type-2 fly ash in standard curing", AIJ J. Technol. Des., vol. 15, no. 31, pp. 627-630, Oct. 2009. (in Japanese)

[5] Japanese Industrial standard, "Fly ash for use concrete", JIS A 6201, 2008. (in Japanese)

[6] T. Hara, Y. Ishikawa, S. Kinoshita, Y. Osaki, "Research on durability of fly ash concrete: Part 2: Properties of fresh concrete", Annual Meeting Architectural Institute of Japan, A-1, pp. 649-650, 2008. (in Japanese)

[7] K. Maekawa, "Promotion of fly ash concrete in sustainable society", JCI Concrete J., vol. 48, no. 6, pp. 3-8, Jun. 2010. (in Japanese)

[8] M. Henry, W. Hirata and Y. Kato, "Environmental performance indicators for concrete containing high volume of recycled materials", Institute of Industrial Science The University of Tokyo, Seisan Kenkyu, vol. 61, no.4, 2009, pp. 633-636.

[9] K. Kaneko, H. Quan, K. Kasami, K. Moriya, "Experimental study on the effects with fineness of fly ash on the properties of concrete", Annual Meeting Architectural Institute of Japan, A-1, pp. 485-486, 2005. (in Japanese)

[10] M. Hisaka, T. Mano and M. Shiraiwa, "Study on the effect of coal ash on the air-entraining properties of concrete", Trans. Cement Concrete, no. 51, pp. 132-137, 1997. (in Japanese)

[11] Y. Sudo, O. Senbu, E. Kamada, "An estimation method of required dosage of air-entraining agent for fly ash concrete", J. Struct. Constr. Eng., AIJ, no. 510, pp. 1-6, Aug. 1998. (in Japanese)

[12] R. Wu, Y. Masuda and S. Nakamura, "Strength efficiency of fly ash in high-strength concrete", J. Struct. Constr. Eng., AIJ, no. 587, pp. 1-6, Jan. 2005. (in Japanese) 
[13] H. Quan, K. Moriya and H. Kasami, "Experimental study on the quality-improving effects of fly ash on higher water content concrete", AIJ J. Technol. Des., vol. 23, pp. 11-14, Jun. 2006. (in Japanese)
[14] R. Wu and Y. Masuda, "A study on carbonation and durability design strength of fly ash concrete", J. Struct. Constr. Eng., AIJ, no. 606 , pp. 15-19, Aug. 2006. (in Japanese)

Received: November 07, 2010

Revised: January 20, 2011

Accepted: February 10, 2011

() Hongzhu Quan; Licensee Bentham Open.

This is an open access article licensed under the terms of the Creative Commons Attribution Non-Commercial License

(http://creativecommons.org/licenses/_by-nc/3.0/) which permits unrestricted, non-commercial use, distribution and reproduction in any medium, provided the work is properly cited. 